\title{
The choice of exchange rate regime for Czech koruna in the context of ERM II participation and the related risks
}

\author{
Mojmír Helísek \\ University of Finance and Administration \\ Crech Republic \\ mojmir.helisek@vsfs.cr. \\ Roman Mentlík \\ University of Finance and Administration \\ Czech Republic \\ roman.mentlik@vsfs.cr.
}

Abstract. Participation in the exchange rate mechanism ERM II (one of the Maastricht criteria - exchange rate stability) is compatible with certain exchange rate regimes only. The aim of this paper is to find arguments for choosing one of these regimes. The starting point is the current strategy of the euro introduction in the Czech Republic, and the expressed concerns about the risks associated with fixing of the exchange rate. The used method is analysis of data on the currency participation in ERM II and searching for analogies of Czech koruna. The analysis consists of the identification of exchange rate regimes used before and after ERM II so that to determine the duration of ERM II involvement. Fixing of the exchange rate in the regime peg with a band of oscillation of $15 \%$ in both directions is the working hypothesis. Criteria of the so-called normal fluctuations margins and the so-called severe tension are also discussed. Development trend of the CZK/EUR exchange rate is examined. The outcome of the research is finding the risks associated with this exchange rate regime. It is the risk of a narrow fluctuation band $(2.25 \%)$ in depreciation direction and the risk in the form of foreign exchange intervention or interest rate differential at excessive appreciation of the exchange rate.

Keywords: ERM II, euro-enlargement, Maastricht convergence criteria, currency crisis, foreign exchange interventions, Czech koruna.

JEL Classification: F31, F33, F36 


\section{INTRODUCTION}

The Maastricht convergence criteria include, inter alia, the exchange rate stability criterion (or the exchange rate convergence criterion). The basic condition for the fulfilment of this criterion is at least two years of participation in the exchange rate mechanism ERM II. To comply with this criterion, the socalled "normal fluctuation margin", without the so-called "severe tension", has to be respected without devaluing the central parity.

Participation in ERM II is compatible only with certain exchange rate regimes. This paper aims to find arguments for the selection of one of these regimes. Which exchange rate regimes are permissible when joining ERM II? Which one of them should be used in the case of the Czech Republic? The starting point of our research is stating the fact that participation in the ERM II means fixing the exchange rate. However, fixed exchange rate is associated with the risk of speculative attacks at foreign exchange markets (and the subsequent currency crisis). There might be other reasons behind the plan to have Czech koruna be involved in ERM II only for a necessary period of time. To determine these reasons, useful would be an analysis of the past experience of the new EU Member States that have already joined the euro area. The analysis consists of the identification of exchange rate regimes used before ERM II involvement and after it, so that to determine the duration of the ERM II involvement. We also search for an analogy with a possible strategy on how to involve Czech koruna in ERM II. We quantify the development trend of $\mathrm{CZK} / \mathrm{EUR}$ and two indicators of the so-called "severe tension" to determine the appropriate exchange rate regime.

The conclusions of our research are applicable to the euro adoption strategy for the Czech Republic. These conclusions may be useful for other countries too, those that are planning to adopt the euro sooner or later (there are six countries that have a temporary exception from the euro adoption, see Table 1).

The structure of the article is as follows. After the literature review, the third part of the paper describes the motivation, i.e., the development of the official attitude to participation in the ERM II. The fourth part (data and methodology) deals with the possible exchange rate regimes compatible with the participation in ERM II as well as the alternative views on the euro adoption in the Czech Republic. The fifth part discusses arguments for the selection of a specific exchange rate regime for future participation of Czech koruna in ERM II. The sixth part (Results) concerns the identification of risks associated with the exchange rate regime.

\section{LITERATURE REVIEW}

We divide the literature into two areas. Firstly, literature which deals with exchange rate regime in the ERM II in general. Second, literature, which deals with the involvement of Czech koruna in ERM II and with the appropriate exchange rate regime.

Exchange rate regimes for ERM II are specified by the European Central Bank in its Policy Position (2003). However, it only lists of inadmissible regimes. Both permitted and inadmissible modes are specified by Fahrholz (2003) and also Komárek et al. (2005), with reference to the documents of the European Commission and the ECB. Antal and Holub (2007), Backé et al. (2004) or Amerini (2003) analyze the use of different exchange rate regimes in ERM II.

O. Dědek (2014) contains both an analysis of the exchange rate stability criterion and its inconsistency with the desired price stability, and a description of the experience of the new EU Member States with the accession to the euro area, i.e. also with fulfilling the criterion under examination. It notes the possibility of application of different exchange rate regime within ERM II, but without any further evaluation of how these regimes were used. It doesn't mention risks associated with different exchange 
rate regimes. Also, H. W. Sinn (2015) describes only the participation of euro area's new Member States in ERM II without assessment which exchange rate regimes have been used in ERM II. ${ }^{1}$

K. Dyson (2006), W. Michalczyk (2011), Backé et al. (2004) or T. Palankai (2015) mention the problems of the participation in ERM II before the entry of new EU Member States to the euro area (risks of speculative attacks). Z. Sychra (2009) points out to the "potential instability" in the period of participation in ERM II. Similar view scan be found in J. Marková (2011).

The Czech Republic's entry into the euro area is studied by a number of authors. The preparation of the introduction of euro and the impact of this introduction is mainly dealt with a study by L. Lacina et al. (2008). This study follows on from the book by L. Lacina, P. Rozmahel, et al. (2010). These publications give an ample attention to the characteristics of ERM II (also challenging its stabilizing role) and hypothetical participation of the Czech koruna in this mechanism. This is mainly associated with the issue of determining the central parity against the euro and the subsequent irrevocable conversion rate. It does not analyse the issue of choosing the appropriate exchange rate regime. However, it states warning against the risk of speculative attacks on the currency, which is in ERM II.

A thorough characterization of ERM II can also be found in M. Helísek et al. (2007), including an explanation of the differences between the participation in ERM II and the fulfilment of the exchange rate convergence criterion (discussing, inter alia, the asymmetric fluctuation bands of $2.25 \%$ and $15 \%$ ). The authors also created a simulation of Czech koruna's participation in ERM II. Although they also mention permissible and impermissible exchange rate regimes within ERM II, they are without any conclusions about the regime suitable for the Czech koruna (despite the fact that the publication was created almost 10 years ago).

The benefits and risks associated with the adoption of euro are discussed in the book by Melísek et al. (2009). Except the general evaluation of the Maastricht convergence criteria, i.e. including the exchange rate stability criterion, it pays no special attention to the participation of the Czech koruna in ERM II.

As part of the preparations for the introduction of euro in the Czech Republic, the official authorities (central bank, ministry of finance and others) have created many technical documents. These are mainly the following: ${ }^{2}$

- National Euro Changeover Plan for the Czech Republic (2007), created by the National Coordination Group for Euro Changeover of the Ministry of Finance,

- since 2004, Assessments of the Fulfilment of the Maastricht Convergence Criteria and the Degree of Economic Alignment of the Czech Republic with the Euro Area have been published annually (Ministry of Finance and the Czech National Bank - CNB),

- the evaluation of the real convergence can be found in Analyses of the Czech Republic's Current Economic Alignment with the Euro Area (Czech National Bank), which annually follow on from the above mentioned Assessments.

These expert documents only mention the obligatory participation of the Czech koruna in ERM II; additionally, the Assessments contain an evaluation of the development of CZK/EUR and simulate the

\footnotetext{
1 Noteworthy is Sinn's proposal to establish rules of leaving the euro area. Exiting the euro area would be only temporary. During this transitional period, a renewed national currency would return into ERM II (pp. 485-489).

${ }^{2}$ In addition to analytical documents by Czech authorities, the nominal convergence of the Czech economy to the euro area is evaluated in the European Commission's Convergence Report and the ECB's Convergence Report, published every two years.
} 
participation in ERM II. The question, what is the appropriate exchange rate regime in ERM II, is not engaged.

\section{MOTIVATION - ADOPTION OF EURO IN THE CZECH REPUBLIC}

By accession to the EU each Member State has committed to, sooner or later, adopt the euro. The deadline for the adoption of euro depends on a decision by political authorities of the EU Member State, naturally only after fulfilling the Maastricht criteria and a positive evaluation by the European Central Bank and the European Commission.

The legislation of the European Union governing the euro introduction in a Member State with the derogation (i.e. temporary exemption from the introduction of the euro) does not include the requirement for the given country's approval. Is it thus possible to impose the euro introduction even without the consent of the given country's political representation? Based on the existing practice of new Member States of the EU, the euro introduction process has always been initiated by the given country's interest. This is also reflected in the National Euro Changeover Plan for the Czech Republic: "After the convergence criteria have been satisfied and the Czech Republic has expressed its will to enter the euro area, the Council of the European Union - acting on the recommendation of the European Commission - will decide on the Czech Republic's entry into the euro area." 3 The fears from forced adoption of euro against the wishes of the government of the country are therefore unreasonable (Helísek, 2015).

Institucionálni zajšténi zavedeni eura $v$ České republice (Institutional Arrangements for Introduction of the Euro in the Crech Republic, November 2005) has set the "working date" for the introduction of euro at 1 January 2010. If euro were to be introduced by this date, the Czech koruna would have had to become involved in ERM II by mid-2007. However, on 25. 10. 2006, the Government decided not to seek entry into ERM II in 2007, which also meant abandoning the original plan to join the euro area in 2010. The Czech Republic's Updated Euro Area Accession Strategy (August 2007) confirmed both the abandoning of the original 2010 deadline, as well as the absence of a specific new date for the scheduled entry into the euro area. According to this strategy (p. 1) "the Czech Republic would stay in ERM II for the minimum possible period." Since 2006, the Assessment of the Fulfilment of the Maastricht Convergence Criteria have every year included the same recommendations to the Government not to set a date for entry to the euro area, which also means not to seek entry into the exchange rate mechanism ERM II.

In general, the preparations for the introduction of the euro have gradually wound down. From April 2011 the so-called "reduced preparations" period begins. These preparations consist only e.g. in the monitoring of international experience, informing the public through a website, editing of methodological texts, etc.

The attitude of the Czech Republic towards the participation in euro area is not unique.

Table 1 informs about the intentions of non-euro area countries to introduce euro.

Interest in joining the euro area appears in two strategic documents of the Government of the Czech Republic. The first is the Economic Evaluation of the Czech Republic's Membership in the European Union after ten years (May 2014) where the benefits of introducing the euro in the form of elimination of exchange rate risk in the euro area trade are underlined, the reduction of transaction costs, the higher attractiveness of the Czech economy for foreign investors etc. The report emphasises, that there is no empirical evidence of the inflationary consequences of the introduction of the euro. The second document is the Policy Concept of the Crech Republic in the European Union (April 2015), which states similar benefits, among other things, the

\footnotetext{
${ }^{3}$ National Coordination Group, 2007, p. 83.
} 
transparency of prices. The introduction of the euro has been identified as a key long-term economic priority for the government.

Table 1

Planned euro area accession date

\begin{tabular}{|c|c|c|c|}
\hline Country & Original date & New date & Preparation stage \\
\hline Bulgaria & $\begin{array}{l}\text { Not set ("as soon as possible } \\
\text { following the fulfillment of the } \\
\text { Maastricht criteria") }\end{array}$ & --- & $\begin{array}{l}\text { Complied Coordination } \\
\text { Council for the preparation of } \\
\text { Bulgaria's membership in the } \\
\text { euro area } *(2015)\end{array}$ \\
\hline $\begin{array}{l}\text { Czech } \\
\text { Republic }\end{array}$ & 1. 1.2010; annulled on 25. 10. 2006 & Not determined & $\begin{array}{l}\text { National Euro Changeover } \\
\text { Plan (2003, update 2007) }\end{array}$ \\
\hline Croatia & Not determined & --- & $\begin{array}{l}\text { Practical preparations have not } \\
\text { commenced }\end{array}$ \\
\hline Hungary & 1. 1. 2010; annulled on 1. 12. 2006 & Not determined & $\begin{array}{l}\text { National Euro Changeover } \\
\text { Plan (updated in 2009) }\end{array}$ \\
\hline Poland & $\begin{array}{l}\text { 1. 1. 2012; annulled at the end of } \\
2009\end{array}$ & $\begin{array}{l}\text { Not determined; "as } \\
\text { soon as possible } \\
\text { following the } \\
\text { fulfilment of the } \\
\text { accession criteria" }\end{array}$ & $\begin{array}{c}\text { National Euro Changeover } \\
\text { Plan (2011) }\end{array}$ \\
\hline Romania & 2015 & 1.1 .2019 & $\begin{array}{c}\text { Interdepartmental commission } \\
\text { established }\end{array}$ \\
\hline Sweden & Not determined & $\begin{array}{c}-- \\
-1\end{array}$ & $\begin{array}{l}\text { Preparations discontinued } \\
\text { upon rejection of the euro in a } \\
\text { referendum of 14. 9. } 2003\end{array}$ \\
\hline Denmark & $\begin{array}{l}\text { Permanent opt-out with regard to } \\
\text { the third stage of the EMU }\end{array}$ & --- & $\begin{array}{l}\text { DKK involved in ERM II } \\
\pm 2,25 \%\end{array}$ \\
\hline Great Britain & $\begin{array}{c}\text { Permanent opt-out with regard to } \\
\text { the third stage of the EMU }\end{array}$ & --- & \\
\hline
\end{tabular}

Source: European Commission, 2014 (b) and previous reports

*http:/ $/$ www.government.bg/cgi-bin/e-cms/vis/vis.pl? s $=001 \& p=0228 \& n=7157 \& g=$

In the development of public opinion about the introduction of the euro in the Czech Republic, the unfavourable attitude towards the introduction of the euro has been maintained. According to research conducted by the Centre for Public Opinion Research in May 2017, only one fifth of respondents are required to introduce the euro (Fig. 1 in Appendix).

According to the Eurobarometer of April 2017, the population of the Czech Republic is very reluctant to introduce the euro: in April 2017, 45\% of the respondents replied that the euro should never be introduced (Fig. 2 in Appendix). It is so close behind Sweden, which rejects the euro the most (51\% respondents to the same question).

\section{DATA AND METHODOLOGY - ANALYSIS OF EXPERIENCES OF THE NEW MEMBER STATES OF EURO AREA PARTICIPATION IN ERM II}

The euro area Member States that adopted euro on 1. 1. 1999 (i.e. 11 countries $^{4}$ ) maintained their exchange rate regime within the ERM with a fluctuation band, specifically with a standard band of $\pm 15 \%$

\footnotetext{
${ }^{4}$ Belgium, Finland, France, Ireland, Italy, Luxembourg, Germany, Netherlands, Portugal, Austria and Spain.
} 
around the central parity mutually against the individual currencies (derived from the ECU parities); in the case of Germany and the Netherlands, it was a narrow band of $\pm 2.25 \%$. The ERM II mechanism was created in 1999, along with the emergence of euro. It replaced the European Monetary System, which was established in 1979.

The ECB refers to "a number of the exchange rate strategies" that may be used within ERM II. However, it explicitly states only strategies incompatible with ERM II, namely: ${ }^{5}$

- free floating

- managed floating without a mutually agreed central rate,

- crawling peg

- pegs against anchors other than euro.

Fahrholz (2003, p. 15) adds that also unilateral euroization is unacceptable for participation in ERM II. Of course, unilateral euroization is not compatible with EU membership (Komárek et al., 2005, p. 25).

Implicitly, only limited options are therefore possible (based on previous experience, contained in Table 2):

- peg against to euro without a fluctuation band,

- peg within ERM II with standard fluctuation band $\pm 15 \%$,

- or with a narrow band which must be agreed in advance,

- euro-based currency board.

Table 2 summarizes the exchange rate regimes of currencies in ERM II for countries that have already adopted the euro.

Table 2

Exchange rate regimes of currencies in ERM II

\begin{tabular}{|l|c|c|c|c|}
\hline \multicolumn{1}{|c|}{$\begin{array}{c}\text { Country } \\
\text { (currency code) }\end{array}$} & $\begin{array}{c}\text { Regime } \\
\text { before ERM II } \\
\text { exchange } \\
\text { rate regime }\end{array}$ & $\begin{array}{c}\text { Regime } \\
\text { in } \\
\text { ERM II }\end{array}$ & $\begin{array}{c}\text { Central parity to } \\
\text { EUR }\end{array}$ \\
\hline Greece (GRD) & $\begin{array}{c}\text { since March 1998 } \\
\text { ERM }\end{array}$ & no & $\begin{array}{c}\text { peg } \\
\pm 15 \%\end{array}$ & 353.109 GRD ** \\
\hline Slovenia (SIT) & $\begin{array}{c}\text { since October 1991 } \\
\text { crawling peg }\end{array}$ & yes & $\begin{array}{c}\text { peg } \\
\pm 15 \%\end{array}$ & 239.640 SIT \\
\hline Cyprus (CYP) & $\begin{array}{c}\text { since January 2001 } \\
\text { peg to euro } \pm 15 \%\end{array}$ & no & $\begin{array}{c}\text { peg } \\
\pm 15 \%\end{array}$ & 0.585274 CYP \\
\hline Malta (MTL) & $\begin{array}{c}\text { since August 2002 } \\
\text { peg }\end{array}$ & 0.4293 MTL \\
\hline Slovakia (SKK) & $\begin{array}{c}\text { since October 1998 } \\
\text { managed floating }\end{array}$ & yes & $\begin{array}{c}\text { peg } \\
\pm 15 \%\end{array}$ & 38.4550 SKK *** \\
\hline Estonia (EEK) & $\begin{array}{c}\text { since June 1992 } \\
\text { currency board }\end{array}$ & no & $\begin{array}{c}\text { currency } \\
\text { board }\end{array}$ & 15.646 EKK \\
\hline Latvia (LVL) & $\begin{array}{c}\text { since February 1994 } \\
\text { peg to SDR } \pm 1 \%\end{array}$ & no & 0.702804 LVL \\
\hline Lithuania (LTL) & $\begin{array}{c}\text { since February 2002 } \\
\text { currency board }\end{array}$ & no & $\begin{array}{c}\text { currency } \\
\text { board }\end{array}$ & 3.4528 LTL \\
\hline
\end{tabular}

Sources: European Central Bank, Convergence Report incl. Technical Annex (various years)

Oesterreichische Nationalbank 2007, pp. 22-23; Amerini 2003, pp. 1-8; Antal and Holub 2007, pp. 314-315; Backé et al. 2004, pp. 14-15.

\footnotetext{
${ }^{5}$ European Central Bank, 2003 (p. 3); however, this opinion practically takes over the Report by the ECOFIN Council (Council of the European Union, 2000, pp. 2-3).
} 


\author{
Notes:* Shares: EUR 70 \%, GBP $20 \%$, USD $10 \%$. \\ ** Revaluation 17. 1. 2000 by $3.5 \%$ (1 EUR = 340.750 GRD). \\ *** Two revaluations: 19. 3. 2007 by $8.5 \%$ (1 EUR $=35.4424$ SKK) and 29. 5. 2008 by $17.6 \%$ (1 EUR \\ $=30.1260 \mathrm{SKK})$.
}

By analysis of data in Table2 the following conclusions will be issued.

Regarding the choice of exchange rate regime, all four regimes were applied (from exchange rate regimes, which we considered permissible). The most common regime (half the time) was peg with a standard fluctuation band of $\pm 15 \%$.

In terms of maintaining or changing the exchange rate system, the countries saw the following developments:

- three countries (Slovenia, Malta and Slovakia) changed the exchange rate regime of their currency upon entering the ERM II,

- the remaining five countries joined ERM II with the previous exchange rate regime (including Greece with its transition from ERM to ERM II). Before joining ERM II, the same exchange rate regime had been maintained for 10 months in Greece, 52 months in Cyprus and the an average of 103 months in the Baltic States.

Table 3 shows the length of new Member States of euro area remaining in ERM II.

Table 3

The length of stay in ERM II

\begin{tabular}{|l|c|c|c|}
\hline $\begin{array}{l}\text { Country } \\
\text { (currency code) }\end{array}$ & In ERM II from & $\begin{array}{c}\text { In euro area since } \text { st }^{\text {st }} \\
\text { January }\end{array}$ & $\begin{array}{c}\text { Number of months } \\
\text { in ERM II }\end{array}$ \\
\hline Greece (GRD) & 1.1 .1999 & 2001 & 24 \\
\hline Slovenia (SIT) & 28.6 .2004 & 2007 & 30 \\
\hline Cyprus (CYP) & 2.5 .2005 & 2008 & 32 \\
\hline Malta (MTL) & 2.5 .2005 & 2008 & 32 \\
\hline Slovakia (SKK) & 28.11 .2005 & 2009 & 37 \\
\hline Estonia (EEK) & 28.6 .2004 & 2011 & 78 \\
\hline Latvia (LVL) & 2.5 .2005 & 2014 & 104 \\
\hline Lithuania (LTL) & 28.6 .2004 & 2015 & 126 \\
\hline
\end{tabular}

Sources: European Central Bank, Convergence Report incl. Technical Annex (various years). Oesterreichische Nationalbank 2007, pp. 22-23.

By analysing the data in Table 3 we come the following conclusions.

Regarding the duration of participation in ERM II, we distinguish three groups of countries:

1) Greece, being an atypical case, unsuccessfully tried to join the euro area in the first wave (from 1999). The Greek drachma had joined the ERM, and therefore it automatically transitioned in 1999 to ERM II, where it remained for 24 months.

2) In 2007-2009, two Central European countries (Slovenia and Slovakia) and two Southern European countries (Cyprus and Malta) joined the euro area. These countries preferred the strategy of the shortest possible participation in ERM II, which averaged 33 months. ${ }^{6}$

\footnotetext{
${ }^{6}$ This period corresponds to the "technical" parameters of entry into the euro area. Roughly half year before joining, it is necessary to request the EC and the ECB to provide Convergence Reports, which must evaluate the previous two-year period.
} 
3) The three Baltic States have taken the strategy of the earliest possible entry into the euro area, thus also into the ERM II. The motives were either economic (to prevent high inflation that occurred under their own monetary policy), and partly political (quickly integrate into European institutions, to avoid potential Russian efforts to influence their economies). However, after an unsuccessful request by Lithuania, which was rejected in 2006, these countries postponed their entry. As a result, their participation in ERM II was delayed by more than 8 years (averaging 103 months).

From the above analysis it is concluded, that there is not even a hint of a coherent approach to the participation of new Member States in ERM II. This concerns both the exchange rate regime and any modifications thereof, as well as the duration of the participation in ERM II. There is no universal approach that could be analogically applied at involving the Czech koruna in ERM II.

\section{THE DURATION OF THE PARTICIPATION AND THE EXCHANGE RATE REGIME IN ERM II FOR CZECH KORUNA}

How long should the Czech koruna remain in ERM II? Which exchange rate regime to choose and why? Several of the new members of the euro area (see Table 3) opted for a strategy of not maintaining the currency in ERM II for longer than absolutely necessary. Also, The Caech Republic's Euro Area Accession Strategy calls for the shortest possible duration of the participation in ERM II. The reason is as follows. "Given that participation in the ERM II [...] does not in itself eliminate the risk of currency turbulence, it is regarded merely as the gateway into the euro area. [...] staying in the ERM II for longer than the minimum required period of two years does not seem desirable" (p. 3). In more detail, this position is elaborated in the study of the Czech National Bank ERM II and the Exchange-rate Convergence Criterion (2003): "The ERM II [...] is a fixed exchange rate regime. [...] In a world of massive capital flows [participation in ERM II] may be associated with potential costs as the financial markets "test" the willingness of the authorities to maintain the exchange rate within the fluctuation band" (pp. 5, 6).

The risk of speculative attacks is also pointed out by other authors: "[...] it must be remembered that formal accession to ERM II, although assumed to result in a higher degree of the exchange rate stability, may cause tensions in the foreign exchange market, being a consequence of speculation and the desire to "test" the authorities by market entities (vide European currency crisis in first half of the nineties)." (Michalczyk, 2011, p. 128) Or: "Acceding countries regard ERM II as an intermediate exchange rate regime, subject to risks of speculative attacks." (Backé et al., 2004, p. 6)

Similar concerns about the participation in ERM II can be found e.g. in the articles of several authors in the book by Dyson (ed., 2006):

- "Critics loath the ERM II as a 'soft peg' prone to speculative attacks" (p. 163). These attacks are due to destabilized expectations of investors, caused by shifts in monetary policy on the one hand, and fluctuations in currency exchange rates on the other.

- The shortest possible period of participation in ERM II is envisaged not only by the Czech Republic but also by other countries, such as Poland: "The concern in both cases is that financial markets will use participation in the ERM II as an excuse to speculate against their national currencies." (p. 99)

Also authors investigating the conditions of accession of the Czech Republic to the euro area (Lacina, Rozmahel et al., 2010), pointed out the risk: "Staying in ERM II for two years presents for candidate countries the risk of speculative attacks on their currency" (p. 21). 
An example of how can currency be in the ERM II threatened by speculative attack is Hungary, which "imitated" participation in ERM II $( \pm$ 15\%) since the year 2001. In February 2008 it introduced a free floating "just due to the speculative threats of the financial crisis" (Palankai, 2015, p. 54)

In the case of the Czech koruna, maintaining a fixed exchange rate is also threatened by the fact that the central bank must follow its priority objective, i.e. low inflation. This is pointed out by Marková (2011, pp. 29-30):

- Currently, the Czech National Bank implements an inflation targeting strategy. The entry into the ERM II will mean following two objectives - internal and external monetary stability, ${ }^{7}$

- The fixed exchange rate regime (especially in the case of fluctuation band of $\pm 2.25 \%$ ) is more vulnerable to speculative attacks on the currency.

Sychra (2009, p. 260) argues that the risks posed by the participation in ERM II involve crises of the ERM II and a forced withdrawal from this system (he reminds the ERM crisis of the early 1990s and the withdrawal of Great Britain from this mechanism). That would complicate the fulfilment of the exchange rate convergence criterion

Unlike the determination of the duration of the participation in ERM II, The Czech Republic's Euro Area Accession Strategy does not include the choice of exchange rate regime for the participation in ERM II. However, this option can be deducted. When selecting this regime, it is necessary to consider the same concerns that justified the duration of the participation in ERM II. Fixed rate "attracts" speculative attacks, leading to currency crisis. The Czech authorities should therefore choose the "softest" fixed exchange rate option (option allowing the maximum exchange rate fluctuations around the central parity), i.e. a peg with a standard fluctuation band.

As for the minimum required period of stay in ERM II, it is necessary to add an important clarification. In assessing whether this condition is met, EC and ECB admit possibility that the time of evaluation, the 24 months does not necessary have to elapse yet. The condition is that in the missing months of this two-year period (prior to ERM II) the exchange rate exhibits necessary stability. That was the case in Finland and Italy (in the original ERM) and Slovenia and Lithuania ${ }^{8}$ (in the case of ERM II).

\section{RESULTS - RISKS ASSOCIATED WITH THE CHOICE OF EXCHANGE RATE REGIME}

At first glance, it seems that the peg with a standard fluctuation band $( \pm 15 \%)$ allows considerable exchange rate fluctuations and thus easy fulfilment of the exchange rate convergence criterion. However, selecting this exchange rate regime is associated with the following two risks.

\subsection{Risk exceeding the normal fluctuation margin}

The interpretation of the exchange rate convergence criterion is not unambiguous. This criterion is in Treaty Establishing the European Community (Art.121) ${ }^{9}$ and in related Protocol no. 21 (Art.

\footnotetext{
7 The "systemic inconsistency" of following two monetary policy objectives, i.e. inflation and exchange rate, particularly in countries with a floating rate where the central banks implemented "inflation targeting" (Czech Republic, Hungary, Poland, Romania or Slovakia) is also noted by Dědek (2014, pp. 147-148). This issue is also thoroughly dealt with by Lacina, Rozmahel et al. (2010, pp. 147-160).

8 Although, Lithuania during its first application to join the euro area did not become a member, however the exchange rate convergence criterion was met.

${ }_{9}$ Treaty on the Functioning of the EU, Article140.
} 
3)formulated as compliance with the "normal fluctuation margin" set by exchange rate mechanism around the central parity against the euro without specifying numerical values10 (for at least two years, without any devaluation of the central parity).

However, this "normal fluctuation margin" is interpreted by the European Commission asymmetrically $-15 \%$ for appreciation and $2.25 \%$ for depreciation. At the same time, the Commission explicitly states that it was ruled out that fluctuations above the $2.25 \%$ limit in the appreciation direction would result in non-fulfillment of the criterion (Commission of the European Communities, 2000, Annex D, s. 67; see for example Helísek, Mentlík 2017, p. 31).

European Central Bank in its aforementioned Policy Position of the Governing Council (December 2003) mentions, when characterizing ERM II, the "standard fluctuation band" of $\pm 15 \%$. When assessing the fulfilment of exchange rate stability criterion it acknowledges, "the width of the fluctuation band within ERM II shall not prejudice the assessment” (European Central Bank, 2003, p. 6).

It is therefore unclear how the EC would evaluate a currency, which would exceed the narrower depreciation band. There has so far been no experience in this respect, because no currency evaluated in ERM II has ever exceeded this band.

Can the Czech koruna be expected to be subject to depreciation pressures? The outlook for the CZK/EUR is shown in Figure 1. Long-term development trend of the CZK/EUR is heading toward appreciation.

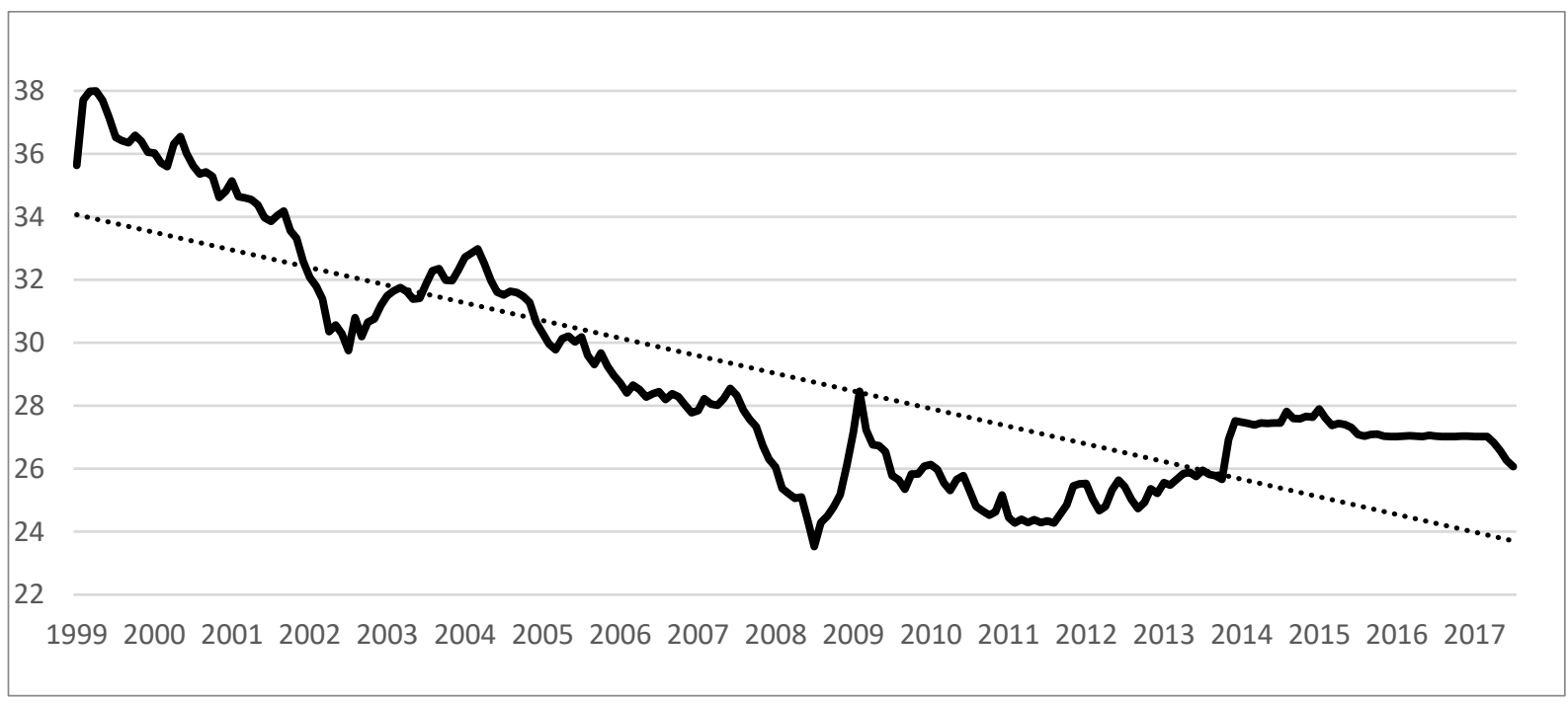

Figure 1. CZK/EUR exchange rate development, monthly exchange rates from January 1999 to July 2017

Source: Czech National Bank

http://www.cnb.cz/cs/financni trhy/devizovy trh/kurzy devizoveho trhu/prumerne mena.jsp?mena=EUR

We will distinguish medium-term fluctuations and a long-term trend in the development of the CZK/EUR exchange rate.

\footnotetext{
${ }^{10}$ In contrast with specific numerical values in case of inflation criteria, the sustainability of public finance and long-term interest
} rates. 


\section{Medium-term fluctuations:}

- appreciation in 2002 due to investors interest in the Czech koruna, due to the successful preparation for the Czech Republic's accession to the EU,

- depreciation in the second half of 2008 - the consequence of general uncertainty in the financial markets and the onset of recession,

- there was a depreciation at the end of 2013 (impact of foreign exchange intervention since November 2013 - see below),

- an appreciation followed the end of the Czech National Bank's foreign exchange market interventions in April 2017.

\section{Long-term trend:}

- The trend line in Fig. 1 clearly demonstrates the long-term appreciation of the CZK/EUR exchange rate,

Linear trend equation:

$$
y=-0.0467 x+34.114
$$

The length of the observation period: 223 months.

- Overall, between January 1999 and July 2017, the trend rate appreciated from 34.11 CZK/EUR to $23.70 \mathrm{CZK} / \mathrm{EUR}$, i.e. $30.53 \%$.

\subsection{Risk of severe tension}

Another risk is the requirement to maintain exchange rate stability "without severe tension". Here, both the European authorities (EC and ECB) agree. This concerns foreign exchange interventions and interest rate differentials against euro area. ${ }^{11}$ However, it is not specified:

- direction of the "severe tension", i.e. whether it concerns devaluation or revaluation,

- amount of interventions and size of the interest rate differentials.

Furthermore, we will carry out the analysis of data (foreign exchange interventions, interest rate differential). However, to be noted in advance, that the criteria are not clearly defined, which does not allow to make clear conclusions about the presence of "severe tension".

Long-term development of the CZK/EUR exchange rate has clearly an appreciating trend. Although it was stopped by foreign exchange interventions carried out by the Czech National Bank since November 7, 2013 to April, 42017 to keep the exchange rate above 27 CZK/EUR. After terminating these interventions the appreciation of CZK/EUR continued (see Figure 1). If this appreciation exceeds the range of $15 \%$ below the central parity, the $\mathrm{CNB}$ would again have to intervene to maintain the exchange rate within the ERM II. European authorities could evaluate further appreciation unfavourably. It was justified by the fact that the intervention on the foreign exchange market is too large, regardless of their appreciation direction.

The permissible level of foreign exchange interventions (i.e. criterion to determine whether there has been a "severe tension") is not specified in any way. Let's try to quantify the current (aforementioned) interventions: 12

${ }^{11}$ European Central Bank, 2003, p. 6. Commission of the European Communities, 2000, pp. 67-68.

12 http://www.cnb.cz/cs/statistika/platebni bilance stat/devizove rezervy/drs rada.htm 
- in the period November 2013 - March 2017, the interventions amounted to CZK 2,428.4 billion (expressed as the increase in foreign exchange reserves of the CNB), i.e. roughly EUR 2.2 billion per month,

- by the end of March 2017 the foreign exchange reserves of the CNB stood at CZK 3,323.2 billion,

- in relation to the average monthly volume of imports (goods + services) in year 2016, these reserves are equivalent to 7.7 months' value, i.e. more than twice the value usually considered sufficient (sufficient means three-month import volume).

The considerable extent of foreign exchange interventions (in the case of hypothetical participation of the Czech koruna in ERM II) could be evaluated as the presence of "severe tensions". The exchange rate convergence criterion would then not be fulfilled even if the exchange rate does not exceed the fluctuation band.

The solution, however, may involve revaluation of the central parity. It is a permissible change. Of the new members of the euro area, the following countries did it during their participation in ERM II:

- Greece in January 2000

- Slovakia, even twice (in March 2007 and May 2008; see notes in Table 2).

To quantify the interest rate differential (Table 4), we use the difference $3 \mathrm{M}$ PRIBOR and $3 \mathrm{M}$ EURIBOR. The observation period is the same as in the case of foreign exchange interventions, i.e. November 2013 - March 2017.

Table 4

Interest rate differential: 3M PRIBOR - 3M EURIBOR (averages, $\%$ and p.p.)

\begin{tabular}{|l|c|c|c|}
\hline \multicolumn{1}{|c|}{ Period } & 3M PRIBOR & 3M EURIBOR & Differential \\
\hline XI-XII 2013 & 0.39 & 0.25 & 0.14 \\
\hline I-III 2014 & 0.37 & 0.30 & 0.07 \\
\hline IV-VI 2014 & 0.36 & 0.30 & 0.06 \\
\hline VII-IX 2014 & 0.35 & 0.17 & 0.18 \\
\hline X-XII 2014 & 0.35 & 0.08 & 0.26 \\
\hline I-III 2015 & 0.34 & 0.04 & 0.29 \\
\hline IV-VI 2015 & 0.31 & -0.03 & 0.34 \\
\hline VII-IX 2015 & 0.31 & -0.03 & 0.34 \\
\hline X-XII 2015 & 0.29 & -0.09 & 0.38 \\
\hline I-III 2016 & 0.29 & -0.19 & 0.48 \\
\hline IV-VI 2016 & 0.29 & -0.26 & 0.55 \\
\hline VII-IX 2016 & 0.29 & -0.30 & 0.59 \\
\hline X-XII 2016 & 0.29 & -0.31 & 0.60 \\
\hline I-III 2017 & 0.28 & $-0,33$ & 0.61 \\
\hline
\end{tabular}

Sources:

http://www.cnb.cz/cnb/STAT.ARADY PKG.PARAMETRY SESTAVY?p sestuid=85\&p strid=AEAB\&p lang =CS

\section{http://www.global-rates.com/interest-rates/euribor/2013.aspx}

Own calculations.

Even at large foreign exchange interventions, the interest rate differential was not significant:

- ranged between 0.07-0.61 p. b.,

- in average reached 0.33 p. b.

Therefore, the development of interest rate differential does not indicate (in the case of a hypothetical participation of the Czech koruna in ERM II) "severe tension". 


\section{CONCLUSION}

The condition for introduction of the euro is at least a two-year participation in the exchange rate mechanism ERM II. Participation in ERM II means to apply some of the fixed exchange rate regimes. The fixed exchange rate is associated with the risk of a currency crisis. This risk affects the strategy of participating in ERM II in two directions:

- remain in ERM II only for the strictly necessary period (it is expressed in The Czech Republic's Euro Area Accession Strategy),

- choose the exchange rate regime for the participation in ERM II (this is in The Strategy not discussed). We came to the conclusion that the risk of currency crisis is the lowest under peg with standard fluctuation band (other possibilities are peg against the euro without a fluctuation band, peg with a narrow band which must be agreed in advance, euro-based currency board).

However, even if this exchange rate regime is chosen, two risks need to be taken into account.

(1) Unlike in the case of mere participation in ERM II (fluctuation band of $\pm 15 \%$ ), according to the European Commission the exchange rate convergence criterion is asymmetric $(2.25 \%$ for depreciation band, 15\% for appreciation band). However, the current developments of exchange rate CZK/EUR show that the Czech koruna can be expected, nor in the future, not to be subject to depreciative pressures. Therefore, there is no such risk.

(2) It is expected that a long-term appreciation trend of the CZK/EUR will continue even after the end of foreign exchange interventions launched in November 2013. If the exchange rate exceeds the limit of $15 \%$ below the central parity, the central bank must take measures to keep the exchange rate within a fluctuation band. These are mainly following two measures. Their use is, however, necessary to consider whether it would not be a manifestation of the so-called "severe tension" (the absence of "severe tension" is a prerequisite for meeting the criterion of a stable exchange rate).

Firstly: the Central Bank will intervene in the foreign exchange market. Permissible level for such intervention is not quantified. Interventions (from November 2013 to April 2017), however, were very high. These interventions, during participation in ERM II, could be therefore evaluated as "severe tension". In this case, however, it is permissible to revalue the central parity.

Secondly: there is a significant change in the interest rate differential (the difference between Czech interest rates and interest rates in the euro area). However, its recent development (in the same period, as foreign exchange interventions) does not indicate "severe tension", as the interest differential was not significant.

We came to the conclusion that none of the risks connected with exchange rate regime peg with standard fluctuation band (during the Czech koruna's participation in ERM II) do not jeopardize the fulfilment of the exchange rate convergence criterion.

\section{ACKNOWLEDGEMENT}

The paper has been prepared under the project "New Sources of Systemic Risk in the Financial Markets", supported by the Czech Science Foundation (No. 16-21506S, 2016-2018).

\section{REFERENCES}

Amerini, G. (2003). Exchange Rates in the Candidate Countries. European Communities: Eurostat. Statistics in Focus. Economy and Finance. Theme $2-39 / 2003$.

Antal, J., \& Holub, T. (2007). Exchnage Rate Arrangements Prior to Euro Adoption. Czech Ecomnomic Review. Acta Universitatis Carolinae Oeconomica, 1(3), 312-323. 
Backé, P. et al. (2004). The acceding countries' strategies towards ERM II and the adoption of the euro - an analytical review. European Central Bank Occasional Paper, No. 10, February 2004. Retrieved from https://www.ecb.europa.eu/pub/pdf/scpops/ecbocp10.pdf

Centrum pro výzkum veřejného mínění (Public Opinion Research Center). (2017). Ob̌́ané ČR o budoucnosti EU a prĭjetí eura - duben 2017 (Citizens of the Czech Republic about the future of the EU and the adoption of the euro - April 2017). Retrieved from https://cvvm.soc.cas.cz/media/com form2content/documents/c2/a4326/f9/pm170524a.pdf

Commission of the European Communities. (2000). Convergence Report 2000. Retrieved from http:/ / ec.europa.eu/economy finance/publications/pages/publication7499 en.pdf

Council of the European Union. (2000). Report by the (ECOFIN) Council to the European Council in Nice on Exchange Rate Aspects of Enlargement, Press Release No. 13055/00, 8 November 2000. Retrieved from http://www.consilium.europa.eu/uedocs/cms data/docs/pressdata/en/misc/13055.en0.html

Czech National Bank. (2016). Analyses of the Czech Republic's Current Economic Alignment with the Euro Area. Retrieved from

http://www.cnb.cz/miranda2/export/sites/www.cnb.cz/en/monetary policy/strategic documents/downlo ad/analyses of alignment 2016.pdf

Czech National Bank. (2003). ERM II and the Exchange-rate Convergence Criterion. Information material for the Czech Government. Retrieved from http://www.zavedenieura.cz/en/documents/euro-area-accession-strategy

The Czech Republic's Euro Area Accession Strategy. Joint Document of the Czech Government and the Czech National Bank. (2003). Retrieved from http://www.zavedenieura.cz/en/documents/euro-area-accession-strategy

The Czech Republic's Updated Euro-area Accession Strategy (Joint Document of the Czech Government and the Czech National Bank) (2007). Retrieved from http://www.zavedenieura.cz/en/documents/euro-area-accession-strategy

Dědek, O. (2014). Doba eura. Úspèchy i nezdary společné evropské mèny (The Era of the Euro. Successes and Failures of the Common European Currency). Praha: Linde.

Dyson, K. (Ed.) (2006). Enlarging the Euro Area. External Empowerment and Domestic Transformation in East Central Europe. Oxford: Oxford University Press.

European Central Bank. (2003). Policy Position of the Governing Council of the European Central Bank on Exchange Rate Issues Relating to the Acceding Countries. 18. 12. 2003. Retrieved from https://www.ecb.europa.eu/pub/pdf/other/policyaccexchangerateen.pdf

European Central Bank. (2014). Convergence Report June 2014. Retrieved from http:/ /www.ecb.europa.eu/pub/pdf/conrep/cr201406en.pdf?4394e06aee28a2d26873f0fde5d0cf96

European Commission. (2014 a). Convergence Report 2014. Retrieved from http://ec.europa.eu/economy finance/publications/european economy/2014/pdf/ee4 en.pdf

European Commission. (2014 b). Fifteenth Report on the Practical Preparations for the Future Enlargement of the Euro Area, Commission Staff Working Document Accompanying the Document. Retrieved from https://ec.europa.eu/info/business-economy-euro/euro-area/enlargement-euro-area/introducingeuro/preparing-cash-changeover en\#progress-reports-on-the-preparations-for-the-enlargement-of-the-euro$\underline{\text { area }}$

European Commission. (2017). Flash Eurobarometer 453. Introduction of the euro in the Member States that have not yet adopted the common currency. Publication $2017 . \quad$ Retrieved from http://ec.europa.eu/commfrontoffice/publicopinion/index.cfm/Survey/getSurveyDetail/instruments/FLA $\underline{\mathrm{SH} / \text { surveyKy/2157 }}$

Fahrholz, Ch. (2003). Strategic Exchange Rate Policy of Accession Countries in ERM II. Ezoneplus Working Paper No. 14. April 2003. Retrieved from http://www.ezoneplus.org/archiv/ezoneplus wp fourteen.pdf

Government of the Czech Republic. (2014). Ekonomické vyhodnoceni clenstvi Céské republiky v Evropské unii po deseti letech. Alternativni scénáre a kvantifikace (Economic evaluation of the Czech Republic's membership in the European Union after ten years. Alternative scenarios and quantification). May 2014. Retrieved from https://www.vlada.cz/assets/mediacentrum/aktualne/finalni-vytistena-verze.pdf

Government of the Czech Republic. (2015). Koncepce politiky Ceské republiky v Evropské unii. Aktivni a srozumitelná Ceská republika v jednotné Evropě (The Concept of Czech Republic Policy in the European Union. Active and understandable Crech 
Republic in a united Europe). April 2015. Retrieved from https://www.vlada.cz/assets/mediacentrum/aktualne/Koncepce-CR-v-EU.pdf

Helísek, M. et al. (2009). Euro v Ceské republice z.pobledu ekonomu (The euro in the Czech Republic from the perspective of economists). Plzeň: Aleš Čeněk.

Helísek, M. (2015). Political Economy of the Euro Introduction in the Czech Republic. In Financial Markets within the Globalization of World Economy. Proceedings of the 7 th International Conference (pp. 82-93). Praha: Vysoká škola finanční a správní. Retrieved from https://is.vsfs.cz/auth/repo/5306/Helisek Fin. trhy 2015 AJ.pdf

Helísek, M. et al. (2007). Vstup ČR do eurozóny, ERM II a kurzové konvergenćni kritérium (Accession of the Czech Republic to the Euro Area, ERM II and Exchange Rate Convergence Criterion). Praha: Vysoká škola finanční a správní.

Helísek, M., \& Mentlík, R. (2017). Simulation of the Czech koruna's participation in ERM II - alternative approaches. Journal of International Studies, 10(2), 28-45. doi:10.14254/2071-8330.2017/10-2/2

Komárek, L. et al. (2005). Kurzové aspekty v procesu pristoupeni Ceské republiky k eurozóné (Exchange rate aspects of the Czech Republic's accession to the euro area). Studie národohospodářského ústavu Josefa Hlávky. Studie 1/2005. Praha: Národohospodářský ústav J. Hlávky.

Lacina, L. et al. (2008). Studie vlivu zavedeni eura na ekonomiku Ceské republiky (Study of the Impact of the Euro Adoption on the Economy of the Czech Republic), $2^{\text {nd }}$ revised edition incl. suggestions from a peer-review process. Bučovice, Martin Stř́žz.

Lacina, L., \& Rozmahel P. et al. (2010). Euro: ano/ne? (Euro: yes / no?) Praha: Alfa.

Marková, J. (2011). Strategie vstupu České republiky do kursového mechanismu ERM II (Strategy of the Czech Republic's Entry into ERM II). Český finanǒni a účetní časopis, 6(2), 18-36.

Michalczyk, W. (2011). An Overview to the Exchange Rate Stability as a Criterion of the Accession to the Euro Zone. Folia Oeconomica Stetinensia, 10(1), 120-130. doi: 10.2478/v10031-011-0013-2

Ministry of Finance of the Czech Republic. (2005). Institucionálni zajisteni zavedeni eura v Ceské republice (Institutional Arrangements for the Euro Changeover in the Czech Republic). Retrieved from http://www.zavedenieura.cz/cs/dokumenty/vladni-materialy/ostatni-dokumenty

Ministry of Finance of the Czech Republic and the Czech National Bank. (2016). Assessment of the Fulfilment of the Maastricht Convergence Criteria and the Degree of Economic Alignment of the Caech Republic with the Euro Area. http://www.zavedenieura.cz/en/documents/fulfilment-of-maastricht-criteria

National Coordination Group for Euro Changeover in the Czech Republic. (2007). National Euro Changeover Plan for the Czech Republic. Retrieved from http://www.zavedenieura.cz/en/documents/national-euro-changeoverplan

Oesterreichische Nationalbank. (2007). The Experience of Exchange Rate Regimes in Southeastern Europe in a Historical and Comparative Perspective. Proceedings of OeNB Workshops. Retrieved from https://www.oenb.at/dam/jcr.../mooslechner tcm16-80923.pdf

Palankai, T. (2015). The Introduction of the Euro and Central Europe. Economics and Sociology, 8(2), 51-69. doi: 10.14254/2071-789X.2015/8-2/5

Sinn, H. W. (2015). Der Euro. Von der Friedensidee zum Zankapfel. München: Carl Hanser Verlag.

Sychra Z. (2009). Jednotná evropská mèna. Realizace hospodárské a mènové unie v EU (The single European currency. Realization of Economic and Monetary Union in the EU). Brno: Masarykova univerzita. 


\section{APPENDIX}

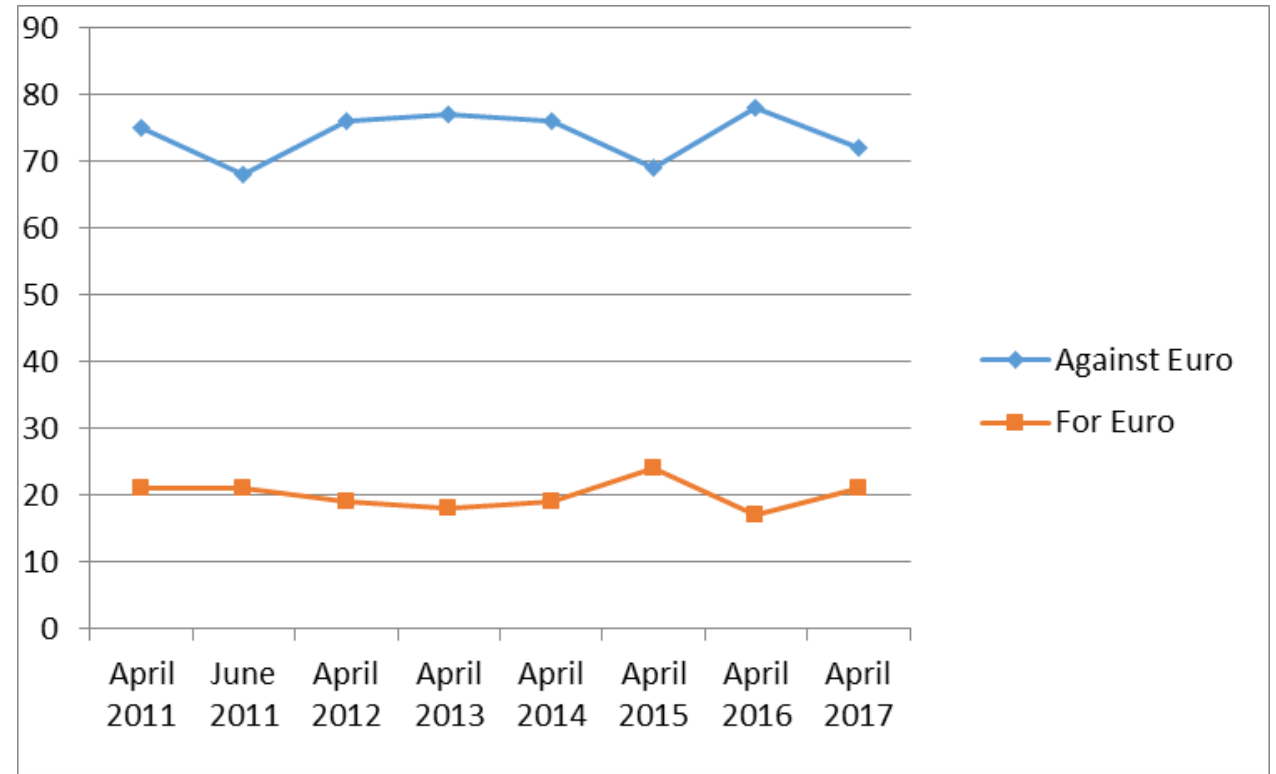

Figure 1. Public opinion on the introduction of the euro in the Czech Republic - CVVM (20112017)

Source: Processed by authors according to data from: Centrum pro výzkum veřejného mínění - CVVM (Public Opinion Research Centre), 2017, p. 4. Research from April 2017. 1033 respondents.

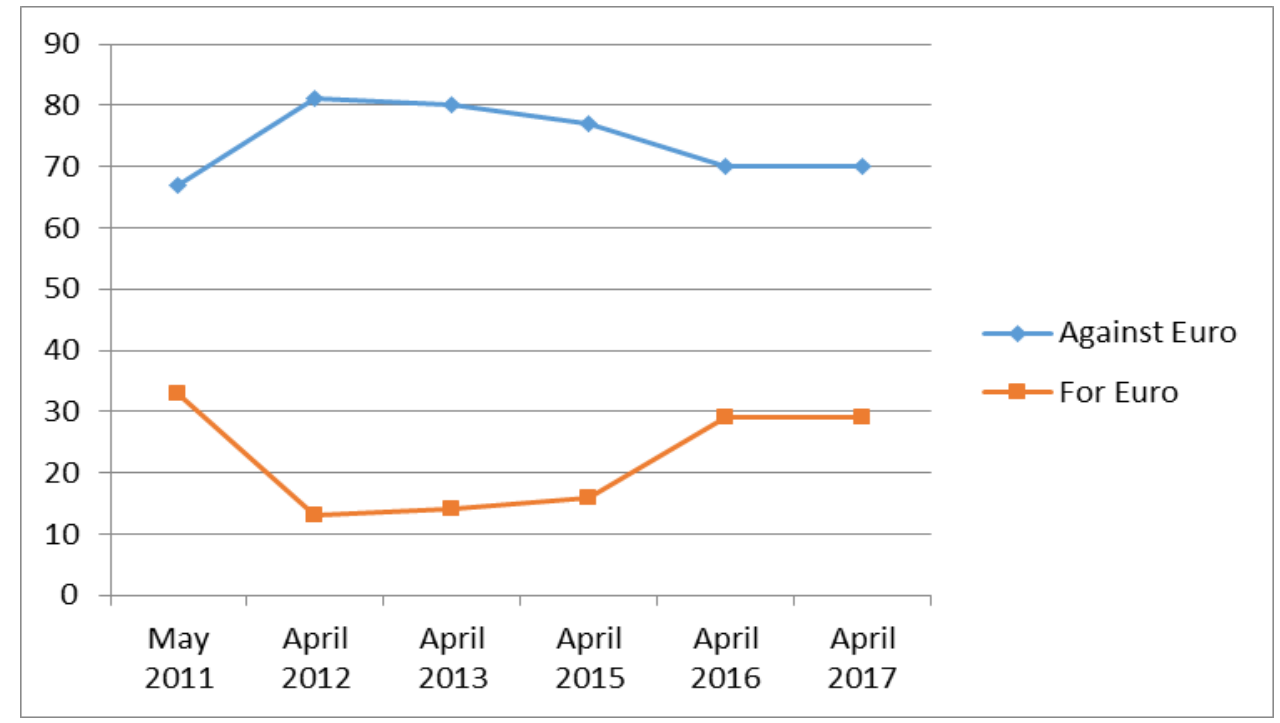

Figure 2. Public Opinion on the introduction of the euro in the Czech Republic - Eurobarometer (2011-2017)

Source: Processed by authors according to data from: European Commission Flash Eurobarometer 453. April 2017, p. 21, and previous reports. 1000 respondents. 